\title{
ZC3H11A wt Allele
}

National Cancer Institute

\section{Source}

National Cancer Institute. ZC3H11A wt Allele. NCI Thesaurus. Code C118347.

Human ZC3H11A wild-type allele is located in the vicinity of $1 \mathrm{q} 32.1$ and is approximately $59 \mathrm{~kb}$ in length. This allele, which encodes zinc finger $\mathrm{CCCH}$ domain-containing protein $11 \mathrm{~A}$, is involved in RNA export. 